\title{
A specimen of little bush moa Anomalopteryx didiformis (Owen, 1844), Emeidae Bonaparte, 1854 from the National Museum of Natural History, Sofia
}

\author{
Zlatozar Boev
}

National Museum of Natural History, Bulgarian Academy of Sciences, 1 Tsar Osvoboditel Blvd, 1000 Sofia, Bulgaria, boev@nmnhs.com, zlatozarboev@gmail.com

\begin{abstract}
A complete right tarsometatarsus from an unknown site of New Zealand was identified as little bush moa (Anomalopteryx didiformis (Owen, 1844)), possibly an adult male individual.
\end{abstract}

Keywords: Dinornithiformes, moa, Anomalopteryx didiformis, extinct birds, New Zealand

\section{Introduction}

The specimen, described here, is the only representative of the order Dinornithiformes Bonaparte, 1852 in the collections of the National Museum of Natural History in Sofia (NMNHS). In a previous paper (Boev, 2005), it was reported as "Dinornithidae gen. indet." of "(Holocene) from an unknown locality in New Zealand". The specimen is a complete right tarsometatarsus (tmt) of very good preservation. The whole bone was burnt, an indication the species had been used as prey of local people. It was given as a gift by Dr Cyril Alexander Walker (1939-2009) from the Natural History Museum, London during the author's short visit in May 1986.

\section{Material and methods}

Material: tarsometatarsus dex. ad. The date, collector's name and the site are unknown.

For the species identification of this subfossil find, we used the special key for identification of the long bones of moas (Worthy, 1988). The measurements of this specimen are given in Table 1.

\section{Results and discussion}

According Worthy (1988), if the ratio TL : WD is less than 2.5, the tmt belongs to a species of Anomalopterygidae. If this ratio is $2.1-2.5$, the key leads

Table 1. Measurement of tarsometatarsus dex. ad. NMNHS 3852 of Anomalopteryx didiformis.

\section{Measurement}

Maximum total length

Width of proximal epiphysis

Width of distal epiphysis

Minimal width of diaphysis

Diameter of condyles medialis of trochlea metatarsi tertii

Diameter of condyles lateralis of trochlea metatarsi tertii

Length of cotyla medialis

$\begin{array}{lr}\text { Abbreviation } & \text { Value (mm) } \\ \text { TL } & 185.00 \\ \text { WP } & 65.93 \\ \text { WD } & 85.15 \\ \text { MW } & 35.89 \\ \text { DM } & 36.69 \\ \text { DL } & 37.00 \\ \text { LC } & 39.64\end{array}$

Received: 7 November 2018 • Editor: Petar Beron 

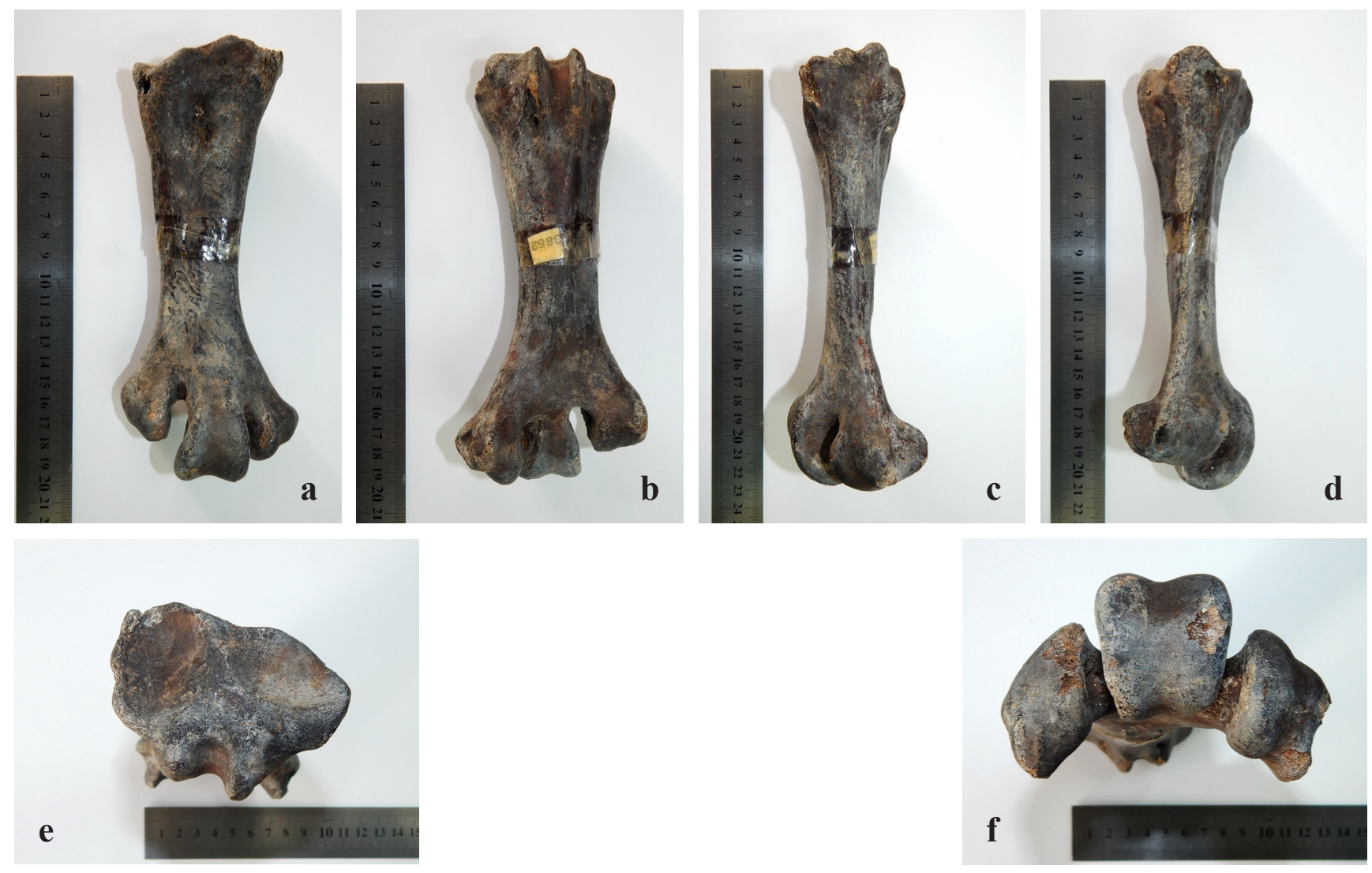

Plate 1. Little bush moa (Anomalopteryx didiformis), tarsometatarsus dex. ad. NMNHS 3852: anterior view - a; posterior view $-\mathrm{b}$; medial view $-\mathrm{c}$; lateral view $-\mathrm{d}$; dorsal view $-\mathrm{e}$; ventral view $-\mathrm{f}$. Scale bar $=2 \mathrm{~cm}$. Photographs: Z. Boev.

to Emeus crassus (Owen, 1846) or Anomalopteryx didiformis (Owen, 1844). The ratio TL : WD of the specimen NMNHS 3852 was 2.17 and fell within the range.

Other features that helped to identify the species as Anomalopteryx didiformis (Worthy, 1988): lateral hypotarsal ridge longer than medial (Plate $1-b$ ); medial nutrition foramen not in distinct hollow, bounded proximally by a ridge (Plate $1-b$ ); length typically 2.2 times distal width (in the specimen NMNHS 3852 it is 2.17 , i. e. approx. 2.2).

Measurements (Cracraft, 1976): TL - 179.02 (n $=43) ; \mathrm{WP}-59.15(\mathrm{n}=41) ; \mathrm{WD}-77.43(\mathrm{n}=42)$. The values of all these measurements for the specimen NMNHS 3852 were very close to them (Table 1). As they exceeded slightly the mean values of Cracraft (1976), I supposed the examined specimen belonged to an adult male individual.

At present, the little bush moa Anomalopteryx didiformis belongs to the family of the emeid moas Emeidae Bonaparte, 1854 (Worthy \& Scofield, 2012).
The species used to be "the more common and occurred on both the North and South islands (Cracraft, 1976). According Day (1981), A. didiformis belongs to the group of the so-called "Pygmy Moas", which used to be between $90 \mathrm{~cm}$ and $120 \mathrm{~cm}$ in height.". The same is stated by Cracraft (1980). The last moas survived until 600 to 800 B.P., although "a small species of Anomalopteryx... may have survived in the remote wilderness of the Southern Alps until the eighteenth or nineteenth centuries." (Cracraft, 1980). The little bush moa used to be abundant at "slightly lower altitudes" (Worthy \& Scofield, 2012).

Anomalopteryx didiformis is known from the Fern Flat, Marton, near the Waimutu Stream, the Kaimatira Pumice Sand (dated 700000 to 800000 years ago), Scinde Island, Hawke's Bay, Near Napier, Hawke's Bay, Gleniti Valley, Timaru, Cook Strait (New Zealand). The finds of "Timaru Basalt, would be about 2.5 m. y. old and would, therefore, be the oldest known fossil record of moa." (Worthy et al., 1991). Another locality where it has been recorded is the Takaka Fos- 
sil Cave on the Takaka Hill, South Island (Worthy \& Roscoe, 2003).

Worthy (1997) summarises that (1) A. didiformis preferred unmodified habitats, (2) it disappeared in the prehistoric time and (3) it is known from a total of 22 sites (9 on the Northern Island and 13 on the South Island).

Thus, the little bush moa is the moa species of both the oldest and the latest fossil/subfossil record of all nine species of Dinornithiformes.

\section{Conclusions}

Although relatively numerous at the paleontological and archaeological sites in the New Zealand, the little bush moa is a rarity among the avian museum collections. The examined tarsometatarsus NMNHS 3852 is one of the most valued specimens in the avian collection of fossil and subfossil birds of the NMNHS.

\section{References}

Boev Z. 2005 Fossil birds in the National Museum of Natural History, Sofia: composition, development and scientific value. Zoologische Mededelingen 79-3 (4): 35-44.

Cracraft J. 1976 The Species of Moas (Aves: Dinornithidae). In: Olson S. (ed.) Collected Papers in
Avian Paleontology Honoring the 90th Birthday of Alexander Wetmore. Smithsonian Contributions to Paleobiology. Smithsonian Institution Press Washington 189-205.

Cracraft J. 1980 Moas and the Maori. Unraveling the evolution and extinction of a large, flightless bird. Natural History 89 (10): 28-36.

Day D. 1981 The Giants. In: The Doomsday Book of Animals. Studio Book. The Viking Press New York 19-25.

Worthy T. 1988 An illustrated key to the main leg bones of Moas (Aves: Dinornithiformes). National Museum of New Zealand Miscellaneous Series 17: $1-37$.

Worthy T. 1997 What was on the Menu? Avian Extinction in New Zealand. New Zealand. Journal of Archaeology 19: 125-160.

Worthy T., Edwards A., Millener P. 1991 The fossil record of moas (Aves: Dinornithiformes) older than the Otira (last) Glaciation. Journal of the Royal Society of New Zealand 21 (2): 101-118.

Worthy T., Roscoe D. 2003 Takaka Fossil Cave - a stratified Late Glacial to Late Holocene deposit from Takaka Hill New Zealand. Tuhinga 14: 4160.

Worthy T., Scofield R. 2012 Twenty-first century advances in knowledge of the biology of moa (Aves: Dinornithiformes): A new morphological analysis and moa diagnoses revised. New Zealand Journal of Zoology 39 (2): 87-153. 